\title{
Study of Influence of Using Various Types of Filler on the Characteristics of Laboratory Mixed AC-BC and AC-WC 2010 Revised General Specification Version III
}

\author{
Muhammad Reza A Maha* and Harmein Rahman \\ Institute of Technology, Bandung-40116, Bandung, Indonesia
}

\begin{abstract}
Filler is a substance that serves as charger cavities of an asphalt mixture. Kinds of filler that can be used are: stone dust, lime extinguished, Portland cement (PC), etc. A small percentage of the filler for asphalt mixture does not mean that does not have a great effect on the properties of Marshall. The erruption of mount Sinabung some time ago at the Tanah Karo, North Sumatra lot leaving the material shed from the eruptions. Then there are around limestone hill in Sipoholon, North Tapanuli Regency, North Sumatera Province too many underutilized by society around. This paper attempts to compare the filler test result from authors with volcanic ash and lime ash againts rock ash as filler AC-BC by researchers previously with only using volcanic ash againts rock ash as filler in AC-WC. The goal from this paper is to knowing if the authors make a volcano ash and lime ash as a filler but this use in ACWC,would be same with the result marshall test requirement from researchers previously. In the step the authors collected result Marshall Test from researches previously. Then Compare with the authors research result [1-3], with provison mix parameter such as compareThe optimum asphalt content from each. Then compare from the result percentage marshall test from authors which make percentage filler from $0-6 \%$ and previously researches from $0-4 \%$. The result from requirement marshall test from percentage marshall $\mathrm{AC}-\mathrm{BC}$ from $0-6 \%$. The Authors earn $4 \%$ while previous research AC-WC earn $3 \%$ which eligible from marshall test requirement.

It can be concluded that make differences mix formula with Volcano ash againts Lime ash or without fly sand from percentage marshall test requirement. Then The layer is same with previous researchers is AC-WC. It would be same result by previously researchers where the result is $3 \%$ from percentage marshall test requirement from $0-6 \%$. it could be happen because from gradation mixing factor from specification requirement from Highway departement in Indonesia.
\end{abstract}

Keywords: AC-BC; AC-WC; Cement; Filler; Hotmix; Lime ash sipoholon; Sinabung mountain ash

\section{Introduction}

\section{Issue background}

Filler is a substance that serves as charger cavities of an asphalt mixture. Kinds of filler that can be used are: stone dust, lime extinguished, Portland cement (PC), etc. A small percentage of the filler for asphalt mixture does not mean that does not have a great effect on the properties of Marshall. The erruption of mount Sinabung some time ago at the Tanah Karo, North Sumatra lot leaving the material shed from the eruptions. Then there are around limestone hill in Sipoholon, North Tapanuli Regency, North Sumatera Province too many underutilized by society around. This paper attempts to compare The filler test result from Authors with volcanic ash and lime ash againts rock ash as filler AC-BC by researchers previously with only using volcanic ash againts rock ash as filler in AC-WC $[4,5]$.

\section{Problem identification}

This Paper make a reveal problem from previous research who did it by undergraduated student. There was a previous resarch who conducted by undergraduated student and my previous research too when I'm still undergraduated student. Then this person make a reseach about hotmix Laboratory AC-WC by added Filler from Volcano ash, which the filler content result from marshall requirement is $3 \%$. Meanwhile from my research about hotmix laboratory AC-BC by added Filler from Volcano ash and Lime ash, which the filler content result from marshall requirement is $4 \%$.

\section{The purpose from paper}

The goal from this paper is to knowing if the authors make a volcano ash and lime ash as a filler but this use in AC-WC,would be same with the result marshall test requirement from researchers previously.

\section{Research Methodology}

Research methodology from previous research (AC-WC)

From The previous Research AC-WC, the researchers make a marshall test by filler content from 1-4\% (Figure 1).

\section{Research methodology from previous research (AC-BC)}

From the previous research $\mathrm{AC}-\mathrm{BC}$, the researchers make a marshall test by filler content from 0-6\% (Figure 2 and Table 1 ).

\section{Data Analysis and Results}

\section{Data Analysis and result from previous research (AC-WC)}

From the data obtained Marshall Test, which meets all the requirements of the specification Department of Public Works in 2010 revison III it was the volcanic ash filler of $3 \%$ that is obtained by the value of stability of $1515 \mathrm{~kg}$, flow amounted to 6, VIM amounted to $4.67 \%$ and VIM PRD 2.18\%, VMA amounted to $15.08 \%$, and its VFB amounted to $69.53 \%$ and the remainder Strength Index of $91.09 \%$.

*Corresponding author: Maha Muhammad Reza A. Institute of Technology, Bandung-40116, Bandung, Indonesia, Tel: +62 22 2500935; E-mail: mahareza93@yahoo.co.id

Received May 31, 2016; Accepted July 19, 2016; Published July 20, 2016

Citation: Maha MRA, Rahman H (2016) Study of Influence of Using Various Types of Filler on the Characteristics of Laboratory Mixed AC-BC and AC-WC 2010 Revised General Specification Version III. J Civil Environ Eng 6: 245. doi: 10.4172/2165-784X.1000245

Copyright: @ 2016 Maha MRA, et al. This is an open-access article distributed under the terms of the Creative Commons Attribution License, which permits unrestricted use, distribution, and reproduction in any medium, provided the original author and source are credited. 


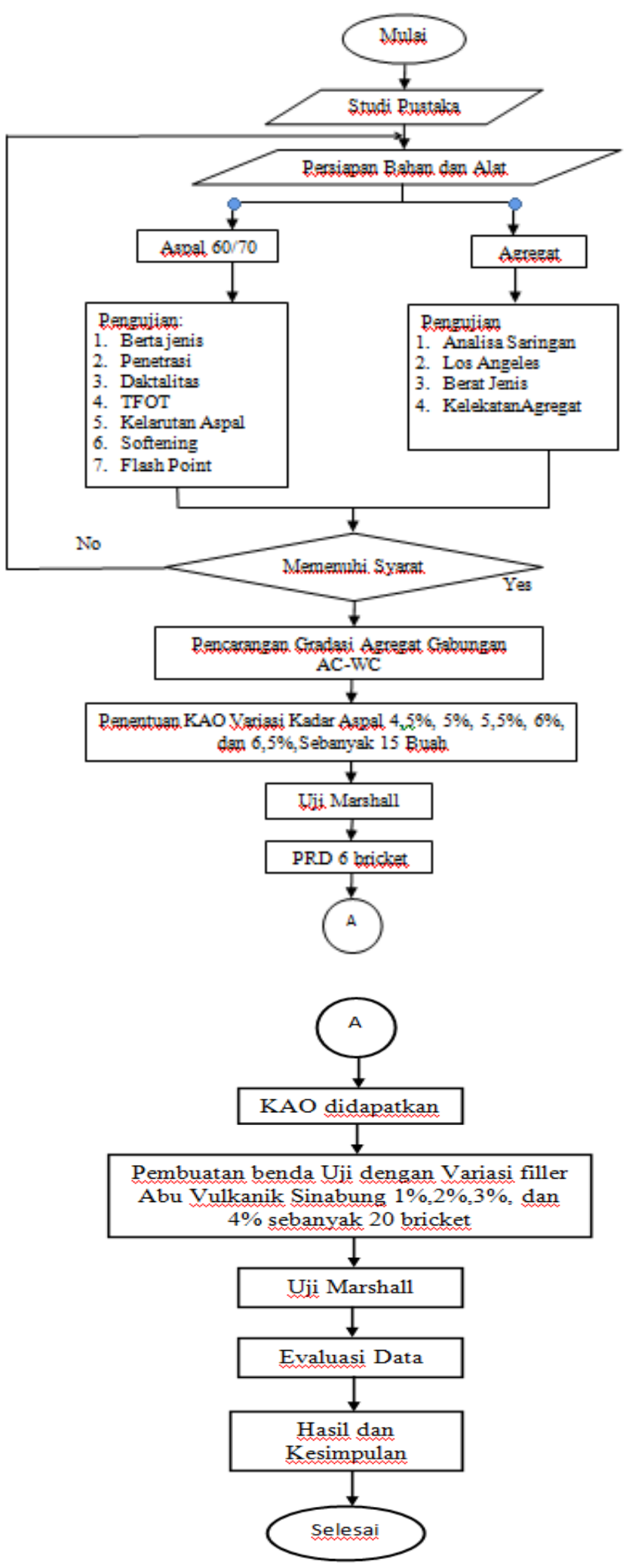

Figure 1: Research methodology from previous reseacrh (AC-WC).
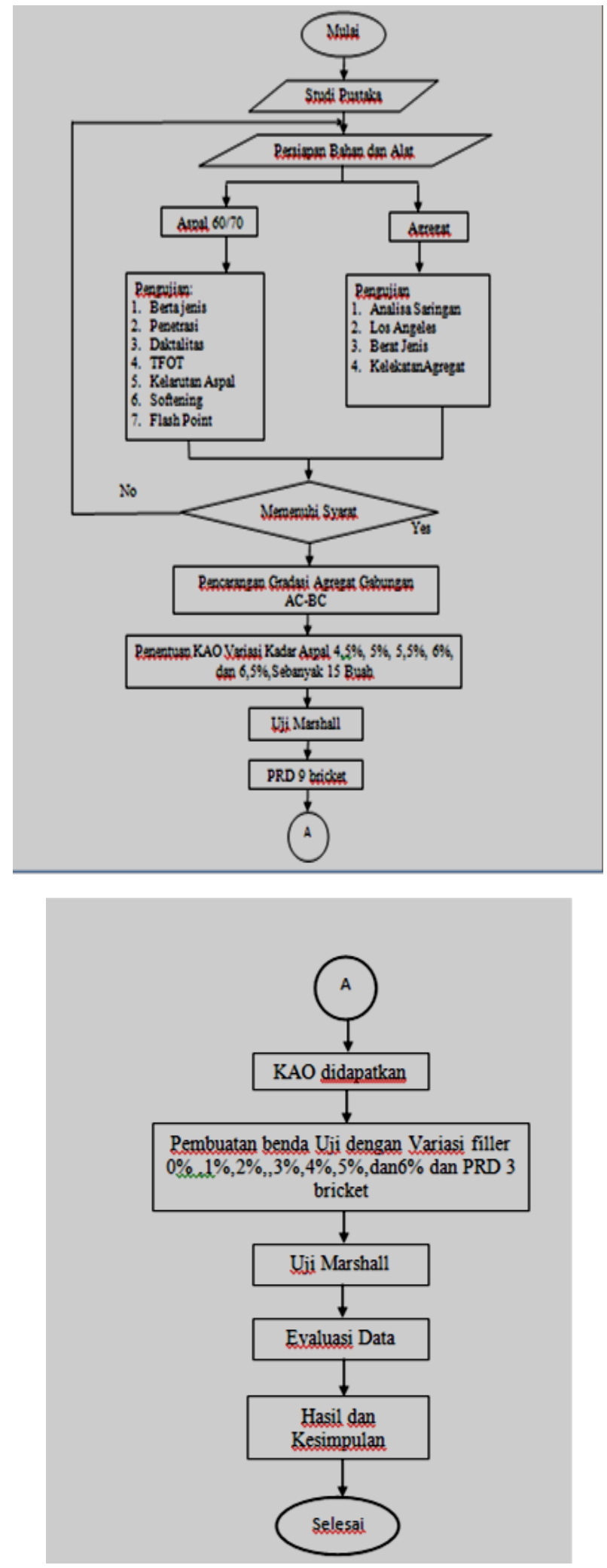

Figure 2: Research metodology from previous research (AC-BC) 
Citation: Maha MRA, Rahman H (2016) Study of Influence of Using Various Types of Filler on the Characteristics of Laboratory Mixed AC-BC and AC-WC 2010 Revised General Specification Version III. J Civil Environ Eng 6: 245. doi: 10.4172/2165-784X.1000245

Page 3 of 5

\begin{tabular}{|c|c|c|c|c|}
\hline & & Laston & & \\
\hline Sifat-sifat Campuran & & Lapis Aus & Lapis Antara & Pondasi \\
\hline Jumlah tumbukan per bidang & & 75 & & $112(1)$ \\
\hline Rasio partikel lolos ayakan $0.075 \mathrm{~mm}$ dengan kadar aspal efektif & Min & & 1.0 & \\
\hline \multirow[t]{2}{*}{ Rongga dalam Agregat (VMA)(\%) } & Maks & & 1.4 & \\
\hline & Min & & 3.0 & \\
\hline \multirow[t]{2}{*}{ Rongga Terisi Aspal } & Maks & & 5.0 & \\
\hline & Min & 15 & 14 & 13 \\
\hline \multirow[t]{2}{*}{ Stabilitas Marshall (kg) } & Min & 65 & 65 & 65 \\
\hline & Min & 800 & & $1800(1)$ \\
\hline \multirow[t]{2}{*}{ Pelelehan } & Min & 2 & & 3 \\
\hline & Maks & 4 & & $6(1)$ \\
\hline
\end{tabular}

Table 1: The requirement Marshall test from Indonesian Road Highway of Departement 2010 Revised General Specification Version III.

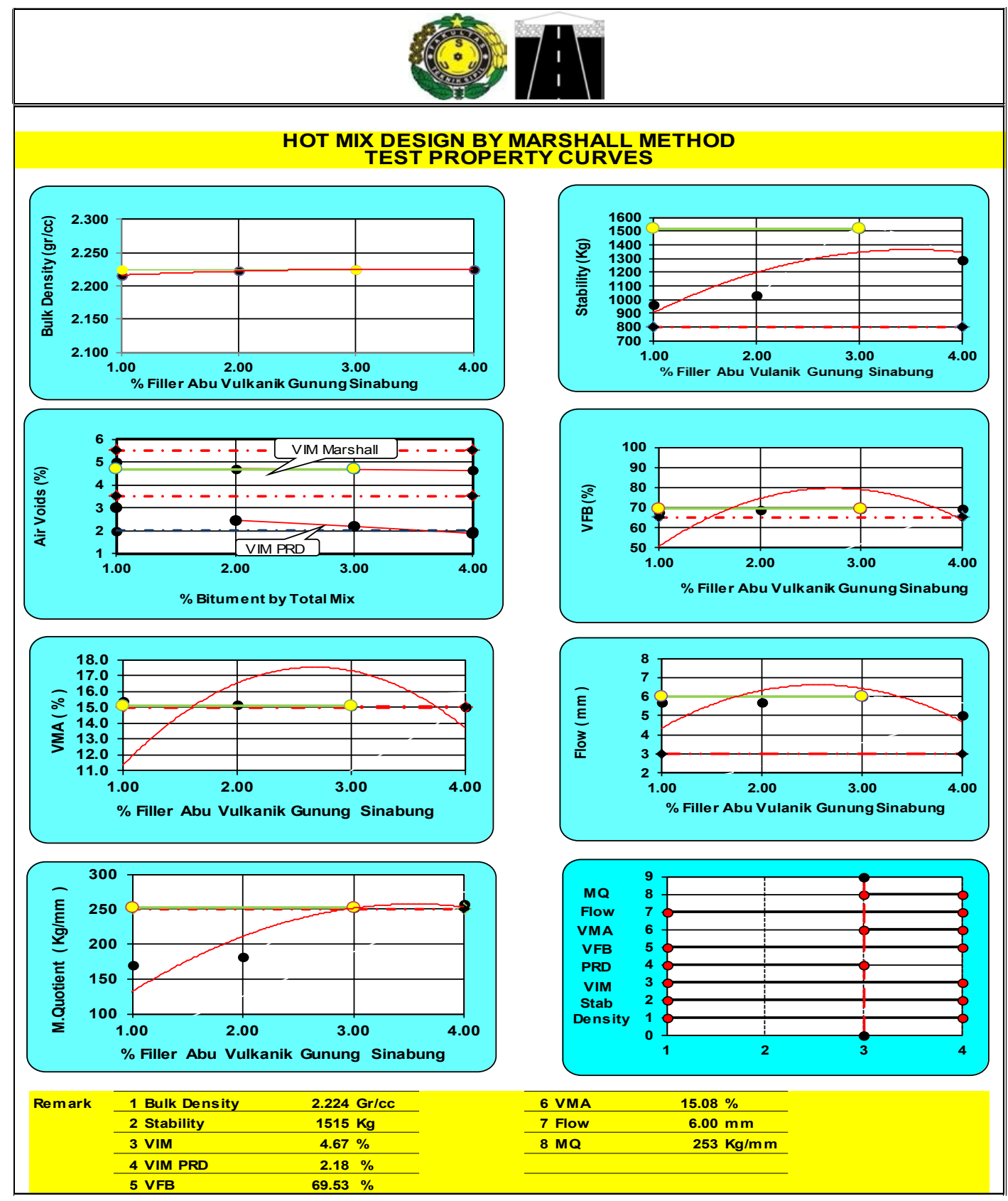

Figure 3: Data analysis and result from previous research (AC-WC) 
Citation: Maha MRA, Rahman H (2016) Study of Influence of Using Various Types of Filler on the Characteristics of Laboratory Mixed AC-BC and AC-WC 2010 Revised General Specification Version III. J Civil Environ Eng 6: 245. doi: 10.4172/2165-784X.1000245

Page 4 of 5

It can be concluded that the filler content of $3 \%$ which meets all the requirements of Marshall Test (Figure 3).

\section{Data analysis from previous research (AC-BC)}

From the data Marshall Test obtained, based on the requirements specification of the Ministry of Public Works in 2010 Revision III is filler which $4 \%$ average filler content from volcanic ash, cement ash and lime ash has obtained the requirement from data Marshall Test by the value of stability of $842 \mathrm{~kg}$, flow amounted to 3.9 , VIM amounted to $4.68 \%$ and VIM PRD $2.33 \%$, VMA amounted to $16.62 \%$, and its VFB amounted to $71.86 \%$ and the remainder Strength Index of $91.31 \%$. It can be concluded that the filler content of $4 \%$ which meets all the requirements of Marshall Test (Table 2 and Figure 4).

\section{Conclusion}

From the data obtained Marshall Test, which meets all the

\begin{tabular}{|c|c|c|c|c|c|c|c|c|c|}
\hline \multicolumn{10}{|c|}{$\%$ Berat Yang Lolos terhadap Total Aggregate dalam Campuran } \\
\hline \multirow{2}{*}{$\begin{array}{l}\text { Ukuran Ayakan } \\
\qquad(\mathrm{mm})\end{array}$} & \multicolumn{2}{|c|}{ Latasir (SS) } & \multicolumn{2}{|c|}{ Lataston (HRS) } & \multicolumn{2}{|c|}{ Gradasi Semi Senjang } & \multicolumn{3}{|c|}{ Laston (AC) } \\
\hline & Kelas A & Kelas B & $\begin{array}{l}\text { Gradasi } \\
\text { Senjang }^{3}\end{array}$ & $\begin{array}{l}\text { Gradasi } \\
\text { Senjang }^{2}\end{array}$ & WC & Base & WC & $B C$ & Base \\
\hline 37.5 & & & & & & & & & 100 \\
\hline 25 & & & & & & & & 100 & $90-100$ \\
\hline 19 & 100 & 100 & 100 & 100 & 100 & 100 & 100 & $90-100$ & $76-90$ \\
\hline 12.5 & & & $90-100$ & $87-100$ & $90-100$ & $90-100$ & $90-100$ & $75-90$ & $60-78$ \\
\hline 9.5 & $90-100$ & & $75-85$ & $65-90$ & $55-88$ & $55-70$ & $77-90$ & $66-82$ & $52-71$ \\
\hline 4.75 & & & & & & & $53-69$ & $46-64$ & $35-54$ \\
\hline 2.36 & & $75-100$ & $50-72^{3}$ & $35-55^{3}$ & $50-62$ & $32-44$ & $33-53$ & $30-49$ & $23-41$ \\
\hline 1.18 & & & & & & & $21-40$ & $18-38$ & $13-30$ \\
\hline 0.600 & & & $35-60$ & $15-35$ & $20-45$ & $15-35$ & $14-30$ & $12-28$ & $10-22$ \\
\hline 0.300 & & & & & $15-35$ & $5-35$ & $9-22$ & $7-20$ & $6-15$ \\
\hline 1.150 & & & & & & & $6-15$ & $5-13$ & $4-10$ \\
\hline 0.075 & $10-15$ & $8-13$ & $6-10$ & $2-9$ & $6-10$ & $4-8$ & $4-9$ & $4-8$ & $3-7$ \\
\hline
\end{tabular}

Note:

1. For the HRS and HRS-WC-base truly gap. at least $80 \%$ aggregate to qualify sieve $8(2.36 \mathrm{~mm})$ must pass a sieve \# 30 (0.600 mm). See Table 6.3 .2 .4 as an example of the limits of "bahab graded gap" in which the material passes No. $8(2.36 \mathrm{~mm})$ and retained on 30 meshes $(0.600 \mathrm{~mm})$.

2. For all kinds of mixed type. refer to Table 6.3.2. (1). (B) for a maximum nominal aggregate size of the stack of material pemasik cold.

3 . If it is not set out in Figure. penggynaan gradation election in accordance with the instructions of the Engineer With reference to section 6.3 of this guide.

Table 2: Combined aggregate gradation envelope for asphalt mixes.

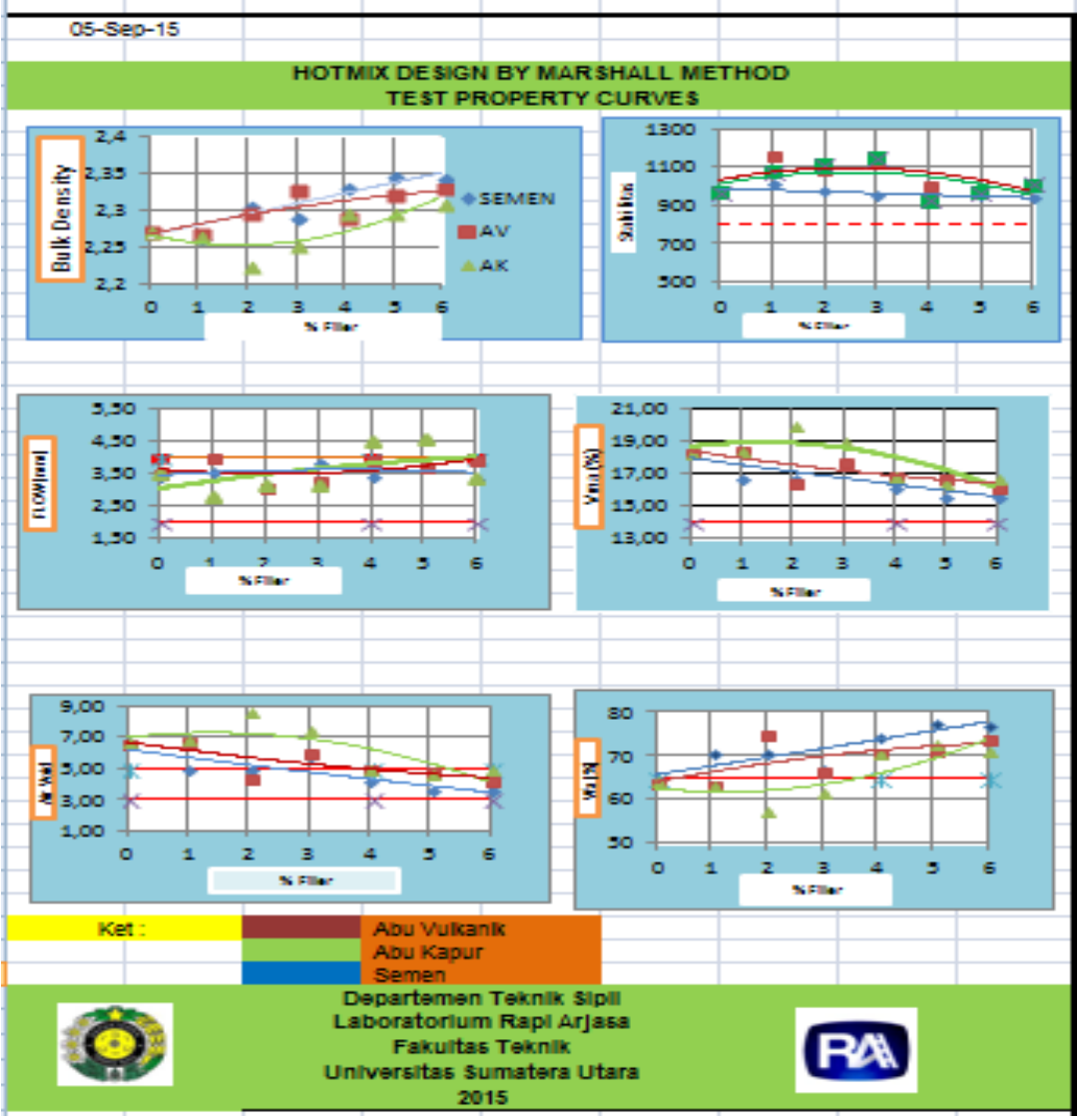

Figure 4: Data analysis from previous research (AC-BC). 
Citation: Maha MRA, Rahman H (2016) Study of Influence of Using Various Types of Filler on the Characteristics of Laboratory Mixed AC-BC and AC-WC 2010 Revised General Specification Version III. J Civil Environ Eng 6: 245. doi: 10.4172/2165-784X.1000245

Page 5 of 5

requirements of the specification Department of Public Works in 2010 Revision III. That The Filler Content $3 \%$ for AC-WC and $4 \%$ AC-BC has meets all requirement marshall test. It can be concluded that make differences mix formula with Volcano ash againts Lime ash or without fly sand from percentage Marshall Test requirement. Then The layer is same with previous researchers is AC-WC. It would be same result by previously researchers where the result is $3 \%$ from percentage marshall test requirement from $0-6 \%$. it could be happen because from gradation mixing factor from specification requirement from Highway departement in Indonesia.

\section{References}

1. Ali $\mathrm{H}$ (2011) Characteristics of asphalt concrete mixtures-wearing course (AC-
WC) with the use of volcanic ash and stone ash as filler. Bandar Lampung, Lampung University of Civil Eng J.

2. Department Pekerjaan Umum (2010) Revision 6.3 specification section III Hot asphalt mixture. The Directorate General of Highways.

3. Muhammad Reza MA (2015) Study of influence of different types of laboratory characteristics filler mixed against AC-BC. General Specification Version 2010 Revision III, Medan. J Civil Eng, University of North Sumatra.

4. Novita Sari SFT (2014) Use of Abu Sinabung as filler for mixed-wearing course asphalt concrete (AC-WC) using general specifications Highways 2010. Medan. J Civil Eng University of North Sumatra.

5. Djoko Ir SU (1979) Highway construction. Jakarta, Handbooks, Publishing Board of Public works. 